\title{
表面のフッ化処理における水素混入の効果
}

\author{
学生員 渋谷 浩司（武藏工業大学) \\ 正員 湯本 雅恵 (武藏工業大学) \\ 正員 堺 孝夫 (武藏工業大学)
}

\section{Effect of hydrogen on fluorination of surface}

Kouji Shibuya, Student Member, Motoshige Yumoto, Member, Takao Sakai, Member (Musashi Institute of Technology)

キーワード：フッ化、流れアフターグロー，水素，フッ化水素

\section{1. まえがき}

材料表面の疎水化の手段として、フッ化炭素プラズマを 用いた表面処理が広く研究されている(1)。フッ素原子:Fは 反応性に富むため、放電空間に試料を設置するのが一般的 であるが、試料が放電にさらされるため、イオンエッチン グによる質量減少、表面層の破壊が問題上なっている。そ こで著者らはそのイオンエッチングの影響を少なくする ため、流れアフターグロー法を用いることにした。具体的 にはへリウムガス:Heを流し、放電空間でHeの準安定励起

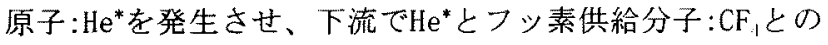
反応によりFを試料表面に供給しようとする考えである。 しかし、高分子材料表面へのフッ素導入量が多くならない ことを経験してきた。そこで、高分子材料の構成元素であ る水素原子:Hのフッ化に及ぼす働きに着目した。

本研究では表面のフッ化処理中に水素分子: $\mathrm{H}_{2}$ 索混入し、 表面に導入されるフッ素の量から水素の影響について検 討を加えたのでその結果について報告する。

\section{2. 実験方法}

実験装置の概略を図1に示す。電極には針対平板電極を 用い、負のグロー状コロナ放電を発生させる。He とCF, の混 合気体を電極上流から導入し、放電空間で励起された $\mathrm{He}^{*}$ が試料付近で $\mathrm{CF}_{4}$ を解離することにより $\mathrm{F} か ゙$ 発生し試料に 供給される(1)式を考えた。

$$
\mathrm{He}^{*}+\mathrm{CF}_{4} \rightarrow \mathrm{He}+\mathrm{CF}_{3}+\mathrm{F}
$$

なお、He $\left(2^{3} \mathrm{~S}\right)$ 励起エネルギー: $19.8[\mathrm{eV}]$ ，放射寿命：

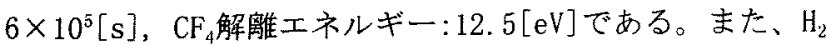
は放電空間より下流から混入した。

実験条件としては $\mathrm{He}: \mathrm{CF}_{4}: \mathrm{H}_{2}=95: 5: 0.02 \sim 0.2$, 全压: $4 \times 10^{3}[\mathrm{~Pa}](30$ [Torr $\left.]\right)$, 気体流量: $10[1 / \mathrm{min}]$, 放電電流: $2[\mathrm{~mA}]$ (実効值), 試料位置: 電極から7.5[cm], 処理時間:
6 [min]で行う。これらの実験条件は予備実験より試料に多 くのフッ素を導入できることから定めたものである。

試料にはフッ素の検出が容易な銅を用い、試料表面の分 析にはXPS:X-ray Photoelectron Spectroscopy (X線光電 子分光分析装置)を用いる。このXPSから検出された $F_{1 s}$ のス ベクトルの面積をフッ素導入量とした。

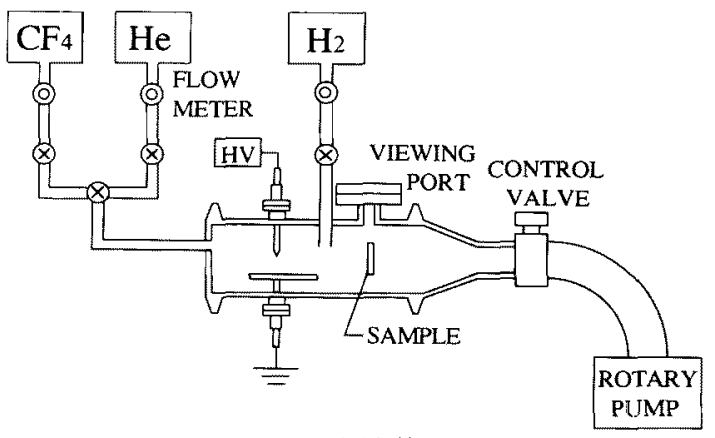

図1. 実験装置

Fig. 1. Experimental apparatus

\section{3. 実験結果と検討}

\section{〈3. 1〉 $\mathrm{H}_{2}$ 混入率に対する試料へのフッ素導入量}

図 $2 に \mathrm{H}_{2}$ 混入率に対する試料入のフッ素導入量の変化を 示す。なお、四には各条件に㧍いて5回の結果の平均と最 大、最小值を示している。

高分子材料の場合、Hとの反応によりFが失われ金属に比 ベ、試料へのフッ素導入量が减少すると考えたが、むしろ $\mathrm{H}_{2}$ 混入により導入されたフッ素の量が增加する結果とな った。 $\mathrm{CF}_{4}$ プラズマ中にH 報告(2)があることから、この原因として $\mathrm{H}_{2}$ と $\mathrm{F}$ の反応によ り $\mathrm{F}$ がフッ化水素:HFとなり、この生成されたHFが試料之 反応していることが考えられる。

〈3. 2〉フッ北水素による反応の検討

$\mathrm{H}_{2}$ の混入により、試料へのフッ素導入量が増加した原因 


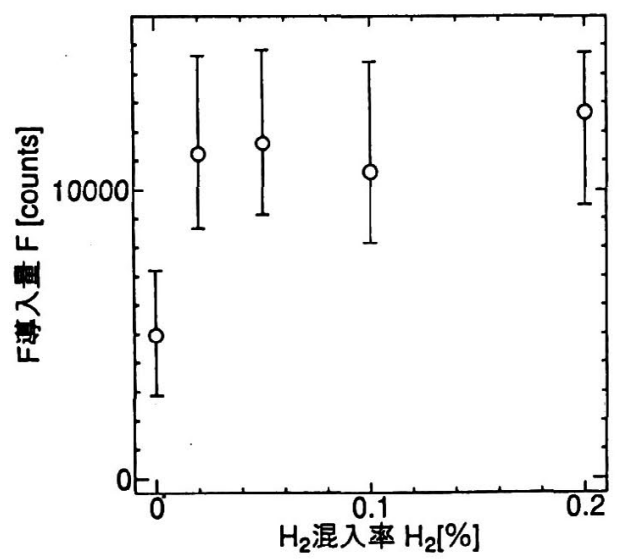

図 2. $\mathrm{H}_{2}$ 混入率に対するフッ素導入量特性

Fig. 2. Fluorine introduced on sample as a function of $\mathrm{H}_{2}$ added in $\mathrm{He}+\mathrm{CF}_{4}$

として、HFと試料の反応を考えた。

そこでHFが試料と反応し、試料へフッ素が導入されるか どうかを調べるために処理気体を $\mathrm{CF}_{1}$ のみと $\mathrm{CF}_{1}+\mathrm{H}_{2}$ の条件 で実験を行った。その結果を図3に示す。なお、処理条件 は $\mathrm{CF}_{4}: 6.7 \times 10^{2}[\mathrm{~Pa}](5.0[$ Torr $]), 0.15[1 / \mathrm{min}], \mathrm{CF}_{4}+\mathrm{H}_{2}$ : 6. $7 \times 10^{2}[\mathrm{~Pa}](5.0[$ Torr $]), \mathrm{CF}_{4}: \mathrm{H}_{2}=15: 0.2 \sim 2, \mathrm{CF}_{4}: 0.15$ [1/min], $\mathrm{H}_{2}: 2 \sim 20[\mathrm{~m} 1 / \mathrm{min}]$ であり、 $\mathrm{CF}_{4}$ の気体流量は図2 の実験条件と時間当りの供給量を同じにしている。

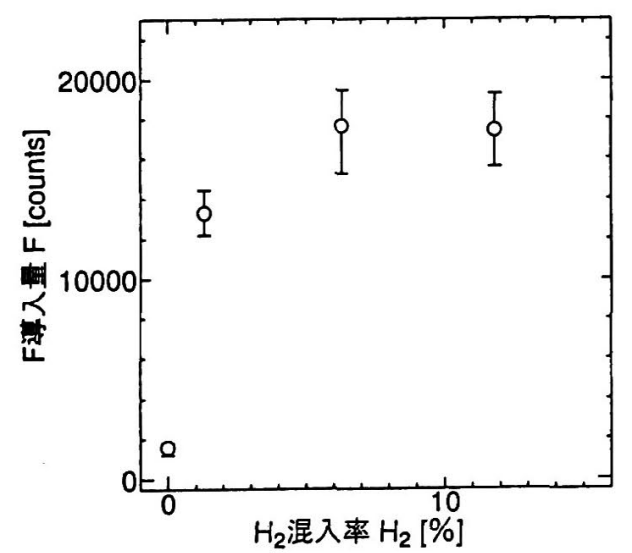

図3. $\mathrm{CF}_{4}$ に $\mathrm{H}_{2}$ を混入した時のフッ素導入量特性

Fig. 3. Fluorine introduced on sample as a function of $\mathrm{H}_{2}$ added in $\mathrm{CF}_{4}$

処理気体が $\mathrm{CF}_{4}$ のみでは極めて反応性の高いF は放電 空間内のみで発生するため、離れた試料まで到達する量は わずかであると思われ、試料への導入量もわずかであるこ とが確かめられた。処理気体が $\mathrm{CF}_{4}+\mathrm{H}_{2}$ の場合には $\mathrm{CF}_{4}$ の供 給量は同じにもかかわらず試料へのフッ素導入量は増加 している。

HFによりグラファイトがフッ化されたとの報告 ${ }^{(3)}$ もり、 HFによ試料へのフッ素導入が生じているものと考えられ る。 また、 $\mathrm{H}_{2}$ 混入により試料へのフッ素導入量が増加した原
因としては、F の場合には極めて反応性が高いため、発生 してもすぐに反応してしまうのに対し、HFは反応性は高い がFよりは安定であるため比較的試料から離れた位置で 発生したHFでもフッ素導入に奇与したものと思われる。

\section{4.まとめ}

材料表面を流れアフターグロー法を用いてフッ化処理 する際の水素の働きを確かめるために実験を行った。その 結果、 $\mathrm{H}_{2}$ を混入することにより、試料へのフッ素導入量は むしろ増加することがわかった。これは $\mathrm{H}_{2}$ とFの反応によ り生成されたHFがフッ化に寄与したためと考えられる。 高分子材料表面へのフッ素導入量が金属に比べ少なく なる原因は明らかにできなかったが、 $\mathrm{H}_{2}$ 混入によりフッ素 導入量を增すことができたことから、高分子材料表面のフ ッ化を行う有効な手段となるものと考えられる。

（平成 9 年 2 月 21 日受付）

\section{文献}

（1）例えば 河西英一・高橋和夫・小駒益弘・森脇隆夫・ 岡崎幸子：「放電法による黒鉛表面のフッ素化」， 表面科学, 6, 2, 30 36 (1985)

(2) H. H. Doh, J. H. Kim and K. W. Whang: "Effect of hydrogen addition to fluorocarbon gases (CF4, C4F8) in selective $\mathrm{SiO}_{2} / \mathrm{Si}$ etching by electron cycrotron rersonance plasma", J. Vac. Sci. Technol. , A14, 3, 1088 1091 (1996)

(3) K. Amine, T. Nakajima and M. Motoyama:"Structure of fluorine-graphite intercalation compounds synthesized in gaseous and anhydrous liquid hydrogen fluoride with fluorine gas", Carbon, 32, 6, 1067 1071(1994)

啮谷 浩司 （学生員）1972年7月29日生まれ。95年

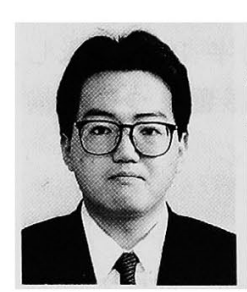
3 月武蔵工業大学工学部電気電子工学科 卒業。97年同大学大学院工学研究科修士 課程修了。現在、株式会社フジクラ勤務
湯本 雅恵 （正員） 電学論A, 116巻, 11号, P992参照
堺 （正員）電学論A, 116巻, 11号, P992参照 